\title{
(j)
}

AL-DZIKRA

Jurnal Studi Ilmu Al-Qur'an Dan Al-Hadits http://ejournal.radenintan.ac.id/index.php/al-dzikra Volume 13, No. 1, Juni Tahun 2019, Halaman 71 - 94

DOI://dx.doi.org/10.24042/al-dzikra.vi3i1.2077

\section{PEMUDA DALAM AL-QUR'AN DAN AS-SUNNAH: PEMUDA ISLAM YANG BERKUALITAS TIDAK LEPAS DARI PENDIDIKAN ORANG TUA YANG TOTALITAS}

\author{
Misbahul Wani \\ UIN Sunan Kalijaga Yogyakarta \\ Misbahul.wani@gmail.com
}

\begin{abstract}
Abstrak
Pemuda adalah aset terpenting dalam sebuah Negara, bangsa, dan Agama. Karena pemuda bukan hanya sekedar harapan regenerasi, akan tetapi adalah bibit-bibit yang akan meneruskan sebuah peradaban hingga datangnya akhir zaman. Jika kita lihat pada kenyataan pemuda saat ini, pemuda Islam mulai kehilangan spirit berjuang, spirit belajar, padahal, sadar maupun tidak disadari (secara otomatis) pemudalah yang akan meneruskan sebuah perjuangan-perjuangan Islam kedepannya. Zaman yang dinamis bukan menjadi alasan untuk mundur, akan tetapi menjadi sebuah alasan untuk bangkit dan mendalami Al-Qur'an dan Sunnah dengan lebih tepat dan bijak lagi. Karena kita juga meyakini bahwa sunnah mengandung pancaran dan teladan dari baginda Agung Nabi Muhammad saw yang sudah terjamin dan menjadi orang terpercaya dalam lingkungan masyarakatnya di Mekkah. Secara garis besar, dalam artikel ini akan mencoba menjelaskan bagaimana pentingnya pendidikan orang tua terhadap terbentuknya pemuda. Dalam kesempatan ini penulis mengangkat kisah Luqman yang kerap memberikan wejangan pada anaknya. Selanjutnya kami menjelaskan bagaimana perhatian Nabi terhadap para kaum muda, serta dampak positif
\end{abstract}


dan negatifnya bagi pemuda. Dengan metode penelitian kualitatif dan pendektan fenomenologi, memberikan arahan secara intelektual dan emosional pada anak agar teguh dan patuh serta tidak menyekutukan Allah swt sebagaimana dalam kisah Lukman.

Kata Kunci: Pemuda, orang tua, Luqman, kualitatif, fenomenologi.

\section{A. Pendahuluan}

Dalam sejarah, sejak dulu bahkan sebelum Islam lahir, Allah selalu mengutus para nabi dan rosul untuk menyampaikan kebenaran dimuka bumi ini. Mereka terpilih dari para pemuda yang pandai bercakap, pandai berdebat dan berani membela hak dan identitas diri. Seperti halnya kita lihat sirah Nabi Ibrahim, sejak kecil beliau sudah berani bertanya dan bercakap bahkan berdebat dengan lingkungannya demi mempertanyakan hal yang menurutnya tidak logis untuk disembah. Cerita beliau telah terekam indah dalam kitab suci umat Islam. Kita juga ingat kisah Ashabul Kahfi yang tergolong pengikut Nabi Isa as. Mereka adalah anak-anak muda yang menolak kembali agama nenek moyang mereka, menolak menyembah selain Allah swt. Mereka bermufakat mengasingkan diri dari masyarakat dan berlindung dalam suatu gua, karena jumlah mereka relatif sedikit yakni tujuh orang di antara masyarakat penyembah berhala. Fakta sejarah ini terekam jelas dalam al-Qur'an surat Al-Kahfi ayat 9-26, yang di antaranya :

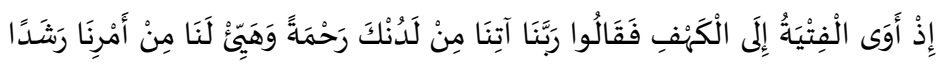

"(Ingatlah) tatkala pemuda-pemuda itu mencari tempat berlindung ke dalam gua lalu mereka berdo'a: 'Wahai Tuhan kami, berikanlah rahmat kepada kami dari sisi-Mu dan sempurnakanlah bagi kami petunjuk yang lurus dalam urusan kami (ini)'.”(Q.S. Al-Kahfi : 10)

Artikel ini akan menjelaskan bagaimana terbentuknya generasi pemuda Islam Indonesia tidak lepas dari pendidikan yang diberikan oleh orang tua kepada anak-anak terlebih kepada para pemudanya. Oleh sebab itu kami mencoba membawa suatu pemahaman yang diangkat dari kisah Luqman dalam al-Qur'an dalam memberikan tausiyah atau arahan pada anaknya. Kami juga akan menjelaskan bagaimana perhatian seorang Nabi Muhammad 
saw terhadap pemuda sebagai generasi selanjutnya, baik agama, bangsa dan Negara.

Langkah selanjutnya kami juga memaparkan sebuah hadis yang menceritakan kisah para pemuda pada zaman Nabi. Dimana nantinya di jadikan sebagai refleksi untuk memacu semangat perjuangan para pemuda kita dalam kehidupan selanjutnya, yang mana nantinya akan membawa sebuah perubahan dengan spirit sunnah yang tertanam dalam jiwa mereka. Karena jika kita liat pemuda Islam Indonesia saat ini mulai kehilangan spirit sunnah sebagai ajaran dan panduan dari Nabi Muhammad saw. Pemahaman secara konteks dan teks nantinya juga akan dipaparkan dalam kajian ini dengan tujuan agar menemukan kesesuaian dengan konteks Indonesia saat ini. ${ }^{1}$

\section{B. Realitas Pemuda Islam Indonesia Zaman Now}

Seiring dengan pertumbuhan anak dan perkembangan zaman, banyak remaja muslim sekarang yang akhlaq dan perilakunya menyalahi aturan agama Islam. Mereka banyak yang tidak memikirkan apakah dampak yang ia lakukan akan menimbulkan banyak kebaikan atau madharatnya. Di era globalisasi ini, dunia dipenuhi dengan berbagai macam teknologi yang canggih. Mulai dari teknologi yang menguntungkan sampai teknologi yang dapat menjerumuskan generasi muda ke dalam jurang kehinaan.

Disini salah satu contoh teknologi yang menjerumuskan generasi muda ke dalam jurang kehinaan adalah media sosial atau internet. Internet adalah salah satu faktor terbesar yang menyebabkan remaja muslim masuk ke jurang kehinaan. Remaja banyak yang mulai memiliki rasa ingin tahu yang berlebihan terhadap suatu hal yang baru. Dari media sosial pun banyak dari remaja yang mulai mengenal lawan jenis. Mulai dari berkenalan, hingga berpacaran. Apabila kita amati, di media sosial banyak remaja mem-posting foto-foto yang menampakkan auratnya sehingga mencuri pandangan dari lawan jenis. Hal tersebut banyak menimbulkan kerugian terhadap mental remaja. Banyak

1 Muhammad Al-Fatih Suryadilaga, Kontekstualisasi Hadis dalam Kehidupan Berbangsa dan Berbudaya, dalam journal KALAM, Volume 11, Nomor 1, Juni 2017, hlm. 217 
dari remaja yang ingin meniru hal tersebut atau bahkan yang dulunya berhijab sekarang memaparkan auratnya demi mengikuti trend remaja sekarang.

Adapun kelemahan etika pergaulan remaja saat ini dipicu oleh beberapa faktor diantaranya: kurangnya perhatian atau pengawasan orangtua, keluarga yang kurang teratur sehingga tidak memperdulikan anak-anakya, pergaulan bebas karena kurang kasih sayang orangtua, kurangnya pengetahuan agama. Dampak lain dari faktor tersebut diantaranya sikap remaja yang mulai tidak peduli dengan hal sekecil apapun dan tidak sopan terhadap hal-hal sepele contohnya tidak memberi salam atau kurang hormat terhadap orangtua, guru ataupun orang lain. Oleh karena itu perlu adanya pembatasan diri diawali dengan diri sendiri agar tidak terjerumus ke hal yang merugikan. ${ }^{2}$

Berkali kali diungkapkan bahwa penyebab utama kerusakan moral para remaja adalah masalah-masalah pengangguran, pergaulan bebas, kerapuhan kepribadian, dan mental yang tak mampu memikul tanggung jawab. Ada yang menyebutkan pula tidak ada control dari pihak orang tua. Akibat dari semua ini mengakibatkan sering terjadi pertikaian, keributan, keonaran, dan pelanggaran-pelangaran di berbagai tempat. Di kantor, di sekolah, di jalan, di gang-gang, para remaja tersebut sering bikin keributan. ${ }^{3}$

Satu kejelian dari pengamatan Ustadz Hasan Al-Nadwi, seorang pakar dan da'i Muslim, yang terkenal menambah keterangannya mengenai beberapa penyebab krisis moral remaja. Yaitu malasnya atau acuhnya perhatian mereka teradap pendidikan dan pengajaran dari guru-guru mereka. Di sisi lain, juga terjadi gejala bahwa para pengajarnya kurang menampakkan jiwa ikhlas sebagai seorang pendidik. Apa yang di ajarkan kurang mengandung isyarat pembinaan di balik pelajaran yang di sampaikan. Guru semata-mata sebagai profesinya untuk penyampai suatu ilmu, adapaun dari sisi kepribadiannya sebagai

${ }^{2}$ Itsna Fitria Rahmah, "Etika Pergaulan Remaja Muslim yang Ramah Ditinjau dari Konsep Peace Education”, Jurnal Pendidikan Madrasah, Volume 1, Nomor 2, November 2016, hlm. 246-247

${ }^{3}$ Hasan Al Banna dkk, Pemuda Militan, (Solo:CV. Pustaka Mantiq, 1992), hlm. 43 
pendidik kurang ditampakkan. Juga pola hubungan pelajar antar pelajar, kurang terbina. Sehingga para siswa tidak memperoleh kebutuhannya di tempat yang semestinya. Akibatnya mereka menjadi liar. ${ }^{4}$

Generasi muda masa kini memiliki kebaikan-kebaikan disamping keburukan-keburukannya. Hal ini mengingat bahwa ia memiliki pelbagai perasaan dan aspirasi yang tidak pernah ada sebelumnya. Ini harus di akui dan diterima. Tetapi disaat yang sama, ia juga dihinggapi pelbagai penyimpangan dalam pemikiran dan prilakunya, yang harus dicarikan jalan keluarnya. ${ }^{5}$ Darah pemuda adalah darahnya para remaja, begitu kata Bang Haji Rhoma Irama dalam salah satu sya'ir dangdut klasiknya. Artinya, pemuda memiliki struggle yang sangat luar biasa demi mewujudkan segala cita-citanya. ${ }^{6}$ Selain masih memiliki daya tubuh yang fit dan sehat, akal pun masih sangat jernih memikirkan masa depan bangsa Indonesia yang lebih maju dan bermartabat.

Cloud Olson, seorang ahli mengatakan: "jiwa muda anak sekarang ini sangat ke enak-enakan, mereka suka malas mencari penghidupan. Seharusnya para pemuda memiliki sikap tidak suka terhadap situasi apa adanya dan bersikap ikut-ikutan melulu. Yang seharusnya mereka memiliki pendirian teguh dan mantap serta pemikiran-pemikiran yang lurus. Tingkah laku dan pemikiran yang ikut-ikutan harus dienyahkan jauh-jauh. Problem ini timbul barangkali karena tidak adanya kesibukan (pengangguran) dan tiadanya hubungan saling mengisi antara orang tua dan anak-anaknya.

Tepat sekali pernyataan Olson ini. Pada kenyataannya para anak remaja memang suka foya-foya di luar rumah. Sementara orang tua tidak mau tahu. Para bapak dan ibu juga para pendidik memiliki tanggung jawab bersama dalam me garahkan mereka,

${ }^{4}$ Hasan Al Banna dkk, Pemuda Militan, (Solo:CV. Pustaka Mantiq, 1992), hlm. 44

${ }^{5}$ Murtadha Muthahhari, Menjangkau Masa Depan, (Bandung: Mizan, 1996), hlm. 72

6 Wahyu Ishardino Satries, "PERAN SERTA PEMUDA DALAM PEMBANGUNAN MASYARAKAT”, Jurnal Madani Edisi I/Mei 2009, hlm. 89 
dan menyelesaikan problem yang mereka hadapi. Ini merupakan salah satu solusi, bukan malah membuat persaingan dengan bertingkah laku seperti mereka juga yang suka menghindari ramah. Satu penyelesaian yang paling mujarab di antara cara-cara lain, adalah memberi eksis mereka di tengah-tengah masyarakat dengan memberi kesempatan berperan terhadap orang banyak. Menumbuhkan hidup bermasyarakat dan berbudaya. ${ }^{7}$

Dalam suatu acara tukar pandang antara Islam dan Nasrani di Lebanon tahun $1388 \mathrm{H}$, hadir sejumlah pakar dari dua Agama. Ustadz In'amullah Khan, sekretaris Mu'tamar Al-Islami dari Karachi mengatakan: "para pemuda kita adalah yang kita harapkan mengendalikan masa depan. Karena itu menjadi tugas generasi kita untuk memprogram mereka sehingga mereka mampu tampil sebagai generasi yang kokoh untuk memikul tanggung jawab masa depan". 8

Pernyataan ini sangat benar, beliau lalu menjelaskan bahwa Islam adalah suatu agama yang sejak awal sangat memperhatikan akhlak. Dan menempatkan generasi tuanya sebagai pelopor yang dibebani tanggung jawab untuk mendidik dan mengarahkan para pemuda pada jalan yang positif. Baik melalui upaya kata maupun keteladanan sikap secara konkrit. Al-Qur'an, sunnah Nabi dan sejarah Islam, selalu mengungkap tentang pendidikan akhlak yang perlu dihujamkan kepada anak sejak masih kecil dan terus diawasi sampai anak berusia remaja.

Satu hal lagi yang secara intensif perlu diperhatikan adalah adanya bahaya infiltrasi budaya Barat yang bersifat materialisme telah merusak akhlak para pemuda Islam. Sikap materialis akan mengancam ruh jihad pemuda-pemudi Islam.

Perkembangan pemuda Islam saat ini sangat luar biasa mengalami kemajuan pemikiran, pergaulan, serta cara pandang terhadap sistem kehidupan sosial. Tapi disisi lain ada dampak negatif dari perkembangan tersebut. Karena pemuda Islam saat ini mulai menyeimbangkan diri dengan pekembangan zaman yang sangat pesat dan modern, mereka mampu menyetarakan diri

${ }^{7}$ Hasan Al Banna dkk, Pemuda Militan, (Solo:CV. Pustaka Mantiq, 1992), hlm. 42

${ }^{8}$ Hasan Al Banna dkk, Pemuda Militan, (Solo:CV. Pustaka Mantiq, 1992), hlm. 43 
dengan kehidupan Barat dalam kehidupan sehari-hari. Namun yang menjadi problematika adalah kehilangan jati diri seorang pemuda Islam Indonesia dengan keislaman dan ke-indonesiaannya. Pemuda sekarang lebih suka mengkonsumsi konsep kehidupan praktis ala Barat dari pada kehidupan ala panduan alQur'an dan as-Sunnah sebagai pedoman kehidupannya.

\section{Pergaulan Bebas Muda-mudi}

Perlu kita perhatikan, pergaulan bebas antara pemudapemudi yang kerap kali melahirkan prilaku seks bebas sekarang ini semakin menggila. Semuanya jelas terekam dalam mode busana, iklan yang mengeksploitasi wanita, hiburan, bahkan dalam cara berfikir mereka yang cenderung didominasi oleh pikiran kotor. ${ }^{9}$ Hal yang sedemikian sudah tidak menjadi hal yang memalukan. Justru melakukan maksiat seakan-akan menjadikan dirinya tinggi dan sebaliknya jika tidak melakukan akan dianggap sebagai orang yang ketinggalan zaman dan tidak tahu perkembangan kehidupan modern.

Aktivitas seks pranikah semakin mewabah dan menjalar bagaikan virus yang mematikan. Pola hidup waqiiyyin ${ }^{d 0}$ dan hedonis melanda sebagian remaja kita. Akibat kronis dari gejala itu, semakin kita rasakan. Prahara seksual telah menjadi salah satu unsur nestapa paradaban manusia. Manusia yang telah terdehumanisasikan, jiwanya semakin mengering akibat menebalnya berbagai pelanggaran terhadap syari'at Islam. Pelecehan seksual, pacaran (sebelum nikah), pornografi, perselingkuhan, prostitusi, pemerkosaan, dan aborsi, sudah menjadi hiasan peradaban hiwari. Inilah kiranya sekilas yang menjadi latar belakang pemikiran dalam memaparkan tulisan ini. ${ }^{1}$

Menurut Hari Moekti dalam bukunya yang berjudul "Generasi Muda Islam" mengatakan: "prilaku kebebasan yang terjadi pada pemuda-pemudi sangat memprihatinkan. Seperti masalah aktivitas seks pranikah, pelecehan seksual, pacaran,

9 Hari Moekti, Generasi Pemuda Islam, (Bandung: Remaja Rosdakarya, 1998), hlm. 45

${ }^{10}$ Pragmatis: megikuti arus.

11 Hari Moekti, Generasi Pemuda Islam, (Bandung: Remaja Rosdakarya, 1998), hlm. 45-46 
pornografi, perselingkuhan, free sex, prostitusi, pemerkosaan, aborsi, prilaku seksual yang tidak normal, dan penyakit-penyakit yang berkaitan dengan kelamin". Menurut beliau, tidak semua masalah tentang seks mesti diketahui oleh umat Islam pada umumnya; yang penting mereka menyadari bahwa kehidupan seks bebas sudah begitu parah dan berbahaya. Dan, yang lebih penting lagi, bagi mereka adalah mengetahui cara menyelesaikan masalah tersebut dari sudut pandang Islam secara tuntas. Sebab jika hanya sibuk menjelaskan lebih detail tentang prilaku seks bebas, mereka hanya menjadi seorang guru yang memberi pengetahuan bukan penyelesaian terhadap persoalan. Meskipun hal yang sedemikian sebenarnya sangat di butuhkan.

Hari Moekti memberikan penjelasan kekurangan kepada para penulis terhadap respon problem pergaulan bebas masih saja terjadi higga saat ini. Salah satu sebabnya adalah kelemahan terhadap para penulis yang masih belum bisa memberikan saran dan jalan yang komprehensif. Kalaupun ada, solusi yang diberikan itu cenderung pragmatis, parsial, tidak komprehensif; serta memberi kesan seolah masalah seksualitas masyarakat sebagai masalah individu semata. ${ }^{12}$

Kekeliruan mereka berawal dari anggapan bahwa syari'at Islam adalah sebuah nilai normal semata. Seperti telah di ketahui, Islam tidak hanya mengatur hubungan manusia dengan Al-Khaliq, tetapi juga hubungan manusia dengan makhluk lainnya, bahkan dengan dirinya sendiri. Dalam Islam, kita tidak hanya menjumpai ketentuan tentang tata cara shalat, zakat,puasa, haji, tetapi juga bagaimana ahlak kita berpakaian, makan, minum, bergaul, dan sebagainya. Artinya, selama ini Islam dipahami hanya sebatas spiritual tapi mengenyampingkan ketentuan-ketentuan dalam kehidupan social, artinya lemah dan cenderung mengabaikan.

Padahal Islam juga mengatur antara manusia dengan manusia lainnya dalam kehidupan masyarakat. Islam menyodorkan sistem pendidikan bahkan aturan pemerintahan yang sangat komplit. Allah swt menjelaskan kesempurnaan Islam ini dalam firman-Nya yang agung:

12 Hari Moekti, Generasi Pemuda Islam, (Bandung: Remaja Rosdakarya, 1998), hlm. 47 


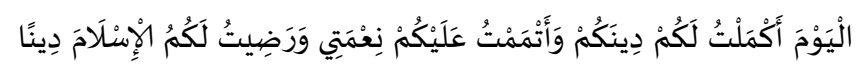

"Pada hari ini telah kusempurnakan untuk kamu agamamu, dan telah kucukupkan kepadamu nimat-Ku, dan telah Kuridlai Islam itu jadi aama bagimu."(Q.S Al-Maidah:3)

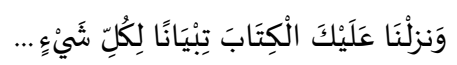

"Dan kami telah turunkan kepadamu Al-Kitab (Al-Qur'an) untuk menjelaskan sesuatu...”(Q.Q. An-Nahl: 89)

Selain itu, permasalahan seks bukan sekadar masalah moral an sich. Permasalahan seks remaja yang sudah tua adalah salah satu permasalahan masyarakat yang terkait erat dengan permasalahan masyarakat lainnya dalam suatu kehidupan. Permasalahan yang begitu rumit dan kait-mengkait itu mustahil dapat diselesaikan hanya dengan nilai moral. ${ }^{13}$

\section{Peran Pemuda}

Pemuda adalah aset suatu bangsa maupun Agama. Pemuda merupakan aset yang sangat mahal dan terpenting dalam kehidupan, selain memiliki kemampuan berpikir secara kritis dan progresif pemuda menjadi harapan masa depan. ${ }^{14}$ Peran pemuda dalam setiap episode sejarah kehidupan suatu bangsa telah terbukti nyata. Sejarah telah mencatat dengan tinta emasnya, bahwa peran pemuda sangat penting dalam proses perubahan suatu bangsa. Bukan hanya sejarah bangsa modern saja, namun bangsa-bangsa atau kaum terdahulu pun tidak terlepas dari kontribusi pemuda di dalamnya.

Yusuf Al-Qardhawi seorang ulama besar Mesir kontemporer berkata, "Apabila ingin melihat suatu negara di masa depan, maka lihatlah pemudanya hari ini". Hal ini menunjukkan bahwa generasi muda memiliki peranan besar dan penting bagi suatu bangsa. Terlebih di masa yang akan datang, kenapa? Karena generasi mudalah yang akan meneruskan estafet kepemimpinan di

13 Hari Moekti, Generasi Pemuda Islam, (Bandung: Remaja Rosdakarya, 1998), hlm. 48

${ }^{14}$ Wahyu Ishardino Satries, "PERAN SERTA PEMUDA DALAM PEMBANGUNAN MASYARAKAT”, Jurnal Madani Edisi I/Mei 2009, hlm. 89 
masa yang akan datang untuk menggantikan para pemimpin yang sekarang.

\section{E. Dampak Peran Pemuda}

Berbicara dampak berarti kita berbicara konsekuensi atau akibat dari suatu sebab. Masa depan adalah akibat, maka ciptakanlah sebab yang baik. Jika dikontekstualisasikan dalam kehidupan pemuda sebagai agent of change in a relegiont and a state, maka yang perlu diperhatikan adalah bagaimana perkembangan dan pola kehidupan pemudanya. Karena pola kehidupan akan mempengaruhi sebuah kehidupan pribadi maupun social, lebih-lebih pada kehidupan pribadi-agama (man and relegion) maupun pribadi-negara (man and state).

Sebagai garis pembatas, sikap yang harus dilakukan oleh kaum muslimin terutama kaum muda, pertama, Islam, secara individu, menganjurkan kepada kita menangkal segala informasi atau data yang masih perlu dipertanyakan dengan bekal keimanan dan ketakwaan yang tangguh (klarifikasi). Yakni, dengan membentuk individu muslim dengan kepribadian yang islami semaksimal mungkin; misalnya, dengan mengadakan ruang dialektik atau pengajian secara intensif, yang akan mempengaruhi cara berfikir dan bersikap seseorang terhadap realitas kehidupan. Pemahaman Islam yang demikian harus benar-benar tertancap dalam benak generasi muslim atau kaum muda, agar mereka memiliki benteng yang kuat, untuk menyaring segala informasi yang diterimanya. Dengan cara in, mereka akan mampu memilah dan memilih segala informasi.

Kedua, kehidupan pemuda tidak bisa lepas dari kehidupan masyrakat, tentu harus ada upaya yang harus dilakukan agar membawa kemaslahatan pada lingkungan, yaitu amar ma'ruf nahi munkar. Sikap tegas dan frontal diperlukan jika terjadi ada ketidakseimbangan yang terjadi dalam masayrakat. Pemuda harus memasang sikap dengan sigap mentutas habis informasi-informasi miring terkait isu yang menjelek-jelekkan Islam. Seperti yang sangat marak di media-media elektronik saat ini. Karena masyarakat hanya sebatas mengkonsumsi saja, maka perlu adanya peringatan dan kepedulian terkait informasi miring yang akan 
merusak ideologi bahkan keimanan masyarakat terhadap agamanya sendiri.

Ketiga, persatuan dan kesatuan kaum muslimin. Berbagai usaha kita akan sulit terwujudkan secara sempurna kalau tidak didukung oleh kekuasaan dan kekuatan yang besar. Jaringan komunikasi yang terorganisasi secara rapi, dan lobi-lobi politik Yahudi, tidak mungkin kita hadapi secara individu. Karena itu, kita sangat memerlukan adanya persatuan dan kesatuan kaum muslimin seluruh dunia. Itulah upaya ketiga yang mesti kita lakukan untuk menghapuskan media Barat tehadap dunia Muslim.

Persatuan umat Muslim seluruh dunia dalam rangka menyelesaikan permasalahan-permasalahan tidak mungkin terealisasi tanpa suatu institusi.

\section{F. Terbentuknya Karakter Pemuda dalam Al-Qur'an dan Perhatian Besar Nabi pada Para Pemuda}

Al-Qur'an telah memberikan petunjuk mengenai sikap keteladanan orang tua dalam mendidik anak-anaknya melalui penggambaran Luqman. Dalam memberikan wasiat-wasiat kepada putra-putranya, Luqman adalah figur seorang ayah yang sangat bijaksana. Itulah sebabnya ayat yang menceritakan tentang Luqman didahului dengan pujian kepadanya. Luqman adalah orang yang mendapatkan hikmah, sedangkan manusia yang memperoleh hikmah, dia telah menerima kebajikan yang luar biasa.

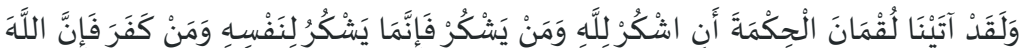

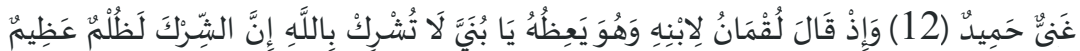

"Dan sungguh telah kami berikan hikmah kepada Luqman, yaitu: "Bersyukurlah kepada Allah. Dan barang siapa yang bersyukur (kepada Allah), maka sesungguhnya ia bersyukur pada dirinya sendiri; dan barang siapa yang tidak bersyukur, maka sesungguhnya Allah Mahakaya lagi Maha Terpuji. Dan (ingatlah) ketika luqman berkata kepada anaknya, di waktu ia memberikan pelajaran kepadanya: "Hai anakku, janganlah kamu mempersekutukan Allah, sesungguhnya mempersekutukan (Allah) adalah benar-benar kezhaliman yang besar." (Luqman: 12;13) 
Sedangakan pada ayat 16 sampai dengan 19, wasiat Luqman kepada putra-putranya itu terangkai sebagai berikut:

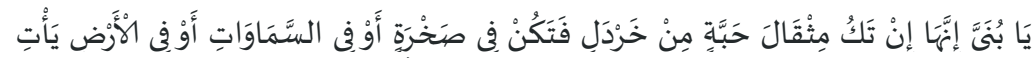

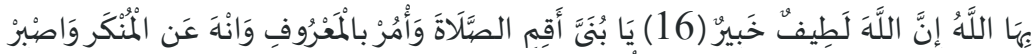

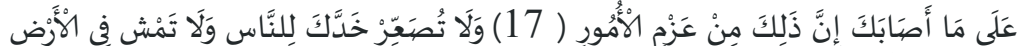

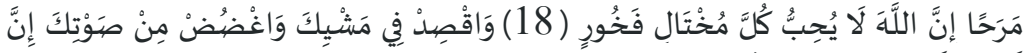

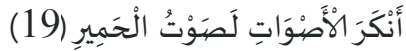

"(Luqman berkata): "Hai anakku, sesungguhnya jika ada (sesuatu perbuatan) seberat biji sawi, dan berada dalam batu atau dilangit atau di dalam bumi, niscaya Allah akan mendatangkannya (membasahinya): sesungguhnya Allah Maha Halus lagi Maha Mengetahui. Hai anakku, dirikanlah shalat dan suruhlah (manusia) mengerjakan yang baik dan cegahlah (mereka) dari perbuatan yang munkar dan bersabarlah terhadap apa yang menimpa kamu. Sesungguhnya yang demikian itu termasuk hal-hal yang diwajibkan (oleh Allah). Dan janganlah kamu memalingkan mukamu dari manusia (karena sombong) dan janganlah kamu berjalan di muka bumi dengan angkuh. Sesunggunya Allah tidak menyukai orangorang yang sombong lagi membanggakan diri. Dan sederhanakanlah kamu dalam berjalan dan lunakkanlah suaramu. Sesungguhnya seburuk-buruk suara adalah suara keledai."

Luqman yang digambarkan dalam al-Qur'an sebagai sosok pribadi seorang ayah yang bijaksana merupakan cermin pendidkan bagi orang tua Muslim dalam mendidik putra-putranya. Dalam wasiat-wasiat tersebut mengandung hakikat-hakikat pendidikan anak yang mendasar, dengan arah tujuan yang jelas tanpa membutuhkan pemikiran rumit.

Melihat kisah arif Luqman dalam al-Qur'an tersebut, orientasinya jika dikaitkan dengan kehidupan pemuda dalam bermasyarakat tidak lepas dari didikan orang-orang yang telah lebih dahulu muda yaitu para sesepuh atau orang tua sendiri. Hubungan diantara keduanya harus ada kolaborasi tentang bagaimana memikirkan masa depan. Sebagai orang tua memberikan arahan terhadap generasi sebagai penerus penegakan agama Islam, bangsa dan Negara. Sebab banyak orang tua maupun tokoh masyarakat enggan memberikan mandat atau kesempatan dalam hal-hal tertentu atau jika dalam bahasa organisasi pengkaderan terhadap para pemuda saat ini minim dilakukan oleh 
orang tua, sehingga tidak jarang para pemuda kehilangan dasardasar hidup bermasyarakat secara lokal maupun universal yang dimiliki oleh para sesepuhnya. Semua itu terjadi karena masih ada saja kebanyakan orang tua -walaupun tidak semuanya- berfikir jika sebuah peran penting diberikan kepada kaum muda, seakanakan martabat dan kedudukannya hilang dimata masyarakat.

Sebenarnya tidak cukup jika para pemuda menunggu dan diberikan nasihat saja oleh orang tua maupun guru. Tapi juga harus ada upaya dari pemuda itu sendiri atau kesadaran beban dan tanggung jawab yang nyata dipundaknya. Sebab jika bukan pemuda yang akan memberi perubahan dan meneruskan perjuangan siapa lagi?. Oleh karena itu tidak heran bapak proklmasi Republik Indinesia Ir. Soekarno mengatakan: "Berilah aku sepuluh pemuda maka akan ku goncang dunia”. Tentu ungkapan ini bukanlah hanya kata tanpa fakta, sebab secara nyata pemuda telah memberikan bukti pada dunia bahwa mereka adalah agen perubahan. Seperti yang terjadi tahun 80 -an, pemudalah yang mampu membubarkan orde baru demi terciptanya Indonesia yang lebih berkeadilan.

Yusuf al-Qardhawi memberikan gambaran kepada pemuda yang tergambar dalam tulisan diatas dikategorikan sebagai generasi idaman. Generasi idaman adalah generasi yang tak asing bagi orang-orang yang membaca al-Qur'an dan mempelajari AsSunnah. ${ }^{15}$ Siapa saja yang membaca al-Qur'an, niscaya menjumpai ciri-ciri generasi idaman tersebut di banyak ayat dan surah. Antara lain dalam surat al-A'raf ayat 181:

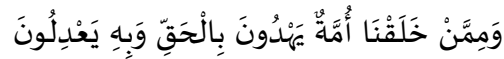

"dan diantara orang-orang yang kami ciptakan ada umat yang memberi petunjuk dengan hak, dan dengan hak itu (pula) mereka menjalankan keadilan" (Al-A'raf:181).

Setelah mengangkat tokoh besar Luqman yang terekam dalam al-Qur'an sebagai pokok pembahasan dalam kaitannya sebagai teladan orang tua muslim mendidik anak atau lebih jelasnya mendidik generasi penerus atau anak pemuda, selanjutnya akan dibahas seperti apa perhatian Nabi Muhammad

15 Dr. Yusuf al-Qardhawi, “Generasi Idaman”, (Jakarta: Media Da'wah, 1990), hlm. 30 
saw terhadap kaum Pemuda. Rasulullah saw senantiasa memberikan pengarahan kepada kaum muda untuk mengikuti jalan kebajikan. Dalam sebuah hadis beliau menegaskan:

"Saya wasiatkan para pemuda kepadamu dengan baik, sebab mereka berhati halus. Ketika Allah mengutus diriku untuk menyampaikan agama yang bijaksana ini, maka kaum mudalah yang pertama-tama menyambut saya, sedangkan kaum tua menentangnya."

Kemudian beliau membacakan ayat al-Qur'an berikut ini:

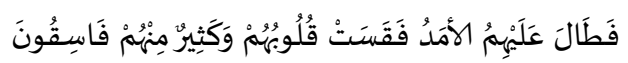

“... Kemudian berlalulah masa yang panjang atas mereka lalu hati mereka menjadi keras.Dan kebanyakan diantara mereka adalah orang-orangyang fasik." (Al-Hadid: 16)

Dalam hadis yang lain, beliau bersabda:

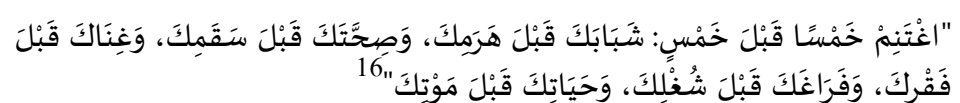

"Raihlah lima perkara sebelum datangnya yang lima: masa mudamu sebelum masa tuamu, kesehatanmu sebelum datangnya sakitmu, kayamu sebelum datangnya miskinmu, kesempatanmu sebelum datangnya kesempitanmu dan dan hidupmu sebelum engkau mati". (H.R. An-Nasai)

Kehidupan di masa muda sangat berarti bagi setiapkehidupan manusia. Karena kelak akan dipertanggungjawabkan di akhirat. Tidak ada pemuda yang mendapatkan naungan ilahi selain yang senantiasa menghambakan dirinya kepada Allah. Rasulullah saw menegaskan tentang beberapa hal yang harus dilakukan guna membimbing kepribadian para pemuda. Diantaranya adalah sebagai berikut:

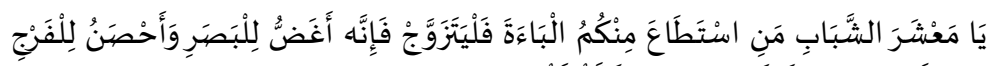

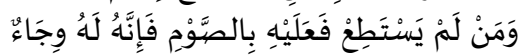

"Hai para pemuda, barangsiapa kuasa beristri hendaklah segera berumah tangga untuk menjaga kehormatan.Tapi barang siapa tidak kuasa melakukannya, hendaklah berpuasa untuk mejadi penawarnya." (H.R. Bukhari dan Muslim)

${ }^{16}$ An-Nasai, Sunan al-Kubra dalam Maktabah Syamilah 
"tidak ada satu pemberian pun yang lebih mulia selain pemberian budi pekerti luhur kepada puteranya"

"Seorang ayah yang mendidik kesopanan kepada anak-anaknya lebih mulia daripada bersedekah setiap hari sebesar satu sha'."

"Hai Ghulam (panggilan sayang kepada anak), saya ajarkan kepadamu beberapa kalimat: "jagalah semua ajaran Allah, niscaya Allah akan menjagamu. Jagalah (ajaran) Allah pasti engkau akan menjumpai Allah di hadapanmu. Jika engkau mengharapkan sesuatu, mohonlah kepada Allah. Dan jika engkau minta bantuan, minta tolonglah kepada-Nya".

Masih bayak ayat dan hadis yang lain tentang petunjuk mengenai pendidikan Islam kepada kaum mudanya. Namun yang lebih utama dikemukakan di sini adalah bahwa Islam sangat memperhatikan pembentukan kepribadian para pemuda. Selagi masih ada, mereka diarahkan agar memiliki budi pekerti yang luhur. Digambarkan oleh Rasulullah saw dalam hadis di atas betapa halusnya hati kaum muda. Mereka masih dalam kesucian hati, tidak banyak kotoran yang melekat di dalamnya. Itulah sebabnya, tatkala pertama kali Islam hadir di tengah kehidupan manusia, merekalah yang mula-mula menyambutnya. Dengan ketulusan dan kesucian hati, mereka siap membela perjuangan Rasulullah saw, dan menentang tradisi para sesepuh mereka yang sesat. $^{17}$

Oleh karena itu Rasulullah saw menganjurkan kepada para orang tua untuk mendidik putra-putranya selagi mereka masi kecil. Saat-saat seperti itulah merupakan waktu yang tepat untuk mengarahkan kepribadian mereka, sebelum mereka mengenal sisi kehidupan yang lain. Penanaman budi pekerti yang baik kepada anak-anak dinilai oleh Nabi sebagai perbuatan yang lebih baik daripada pemberian sedekah kepada orang lain.

Kepada remaja yang telah menginjak usia dewasa, Islam menganjurkan agar segera melangsungkan pernikahan. Hal ini dimaksudkan untuk menghindari bergejolaknya nafsu seksual yang tidak terkendali. Bila anjuran tersebut belum mampu

${ }^{17}$ Hasan Al Banna dkk, Pemuda Militan, (Solo:CV. Pustaka Mantiq, 1992), hlm. 63 
dilaksanakan, berpuasa merupakan langkah yang terbaik untuk meredam nafsu birahi.

Masa muda hendaknya dimanfaatkan untuk melakukan perbuatan yang baik, sebab kesempatan itu hanya datang satu kali dalam rentang kehidupan manusia di dunia. Tenaga yang masih segar di tambah dengan semangat yang menyala merupakan modal utama untuk mengejar kesempatan emas menyongson masa depan yang gemilang melalui ilmu pengetahuan. Pada saat usia menua nanti, kesempatan itu tidak banyak diharapkan. Karena sejalan dengan bertambahnya umur, kesehatan semakin menurun dan semangat hidup juga melemah. Itulah sebabnya, selagi masih menunjukkan ketegaran di kala usia muda, kesempatan menunaikan kewajiban membela agama Allah hendaknya dimanfaatkan sebaik-baiknya. ${ }^{18}$

Apabila hidup kita diabdikan guna kepentingan agama, niscaya Allah akan senantiasa melindungi dan memayungi setiap gerak langkah kita. Kemanapun kaki kita melangkah untuk mencari rezeki maupun kepentingan lainnya, hidayah Allah senantiasa menaungi. Maka kemudahan akan selalu menyertai serta terhindar dari segala malapetaka. Oleh karena itu, hendaknya semua tindakan kita hanya tertuju untuk mengharap ridha Allah swt semata. Dialah Yang Maha Perkasa di atas alam raya ini. Dia telah menetapkan rezeki dan semua keputusan yang berhubunga dengan mahluk-Nya. Rasulullah saw juga menganjurkan kepada kaum remaja muslim untuk senantiasa menunaikan shalat dan menjadikan sebagai kebiasaan yang baik. Sebab shalat merupakan ibadah wajib yang dapat mencegah dari perbuatan jahat sebagaimana di jelaskan dalam al-Qur'an.

Nabi juga memberikan pengarahan kepada para orang tua untuk senantiasa memperhatikan perkembangan kepribadian anak-anaknya. Misalnya di kala mereka menginjak usia remaja, para orang tua hendaknya memisahkan tempat tidurnya. Dalam usia-usia peralihan seperti inilah, para remaja sedang berproses mencari bentuk dirinya. Maka sudah sepatutnya mereka mendapatkan pengawasan dan bimbingan yang lebih besar agar

${ }^{18}$ Hasan Al Banna dkk, Pemuda Militan, (Solo:CV. Pustaka Mantiq, 1992), hlm. 64 
kepribadian jiwanya tumbuh dengan baik. Hal ini sangat penting bagi perjalanan hidup mereka selanjutnya.

Pendidkan budi pekerti sangat menentukan bagi kehidupan sang anak. Dengan mendidik mereka sedini mungkin, kepribadian dan akhlaknya akan tumbuh menurut arah yang ditentukan oleh ajaran-ajaran Islam guna memperoleh kebahagiaan hidup sejati.

Itulah yang di maksud penulis dengan istilah kehidupan pemuda Islam dengan spirit istilah sunnah. Hal ini sebenarnya sama dengan ungkapan ilmuan hadis modern 'living hadis' atau 'ihyaa' as-Sunnah'. Namun yang dijadikan objek adalah pemuda Islam Indonesia yang membawa semangat kehidupan sehari-hari dalam menjalani kehidupan bermasyrakat. Sebelum lebih jauh kita bahas inti permasalahan, penulis akan sekilas menjelaskan pengertian sunnah. Mengenai pengertian sunnah para ilmuan Islam sangat varian mendefinisikannya, namun saya akan mengambil perspektif ilmuan fiqih saja yang lebih mendekati kriteria pembahasan secara amaliah. Menurut ulama fiqih, sunnah adalah semua amalan yang berpahala ketika dikerjakan dan tidak berdosa ketika ditinggalkan.

Jika kita melihat perhatian yang begitu besar dilakukan oleh Nabi, tentu harus ada suatu disiplin ilmu yang harus dijadikan mediasi untuk memperoleh pemahaman. Berbicara as-Sunnah, tidak bisa lepas dari panduan hadis sebagai rujukan utama umat Islam. Di kalangan sahabat senantiasa memahami dan melaksanakan ajaran yang dibawa oleh Nabi Muhamamd saw. Segala problem kehidupan keseharian baik individu maupun bermasyarakat serta bernegara ditanyakan langsung kepada Nabi saw. Namun, seiring dengan wafatnya Rasulullah saw. para sahabat kemudian mendiskusikannya dan saling cek dan ricek untuk mendapatkan hadis yang diinginkan dan sekaligus melaksanakannya. ${ }^{19}$

Melihat konteks diatas, jika dikaitkan dengan saat ini pemuda Islam Indonesia harus lebih semangat belajar dan mencari berbagai macam solusi untuk memecahkan masalah-masalah yang ada di Indonesia sekarang ini. Perkembangan zaman seharusnya

19 Muhammad al-Fatih Suryadilaga, "Kontekstualisasi Hadis dalam Kehidupan Berbangsa dan Berbudaya" dalam journal KALAM, Volume 11, Nomor 1, Juni 2017, hlm. 217 
tidak menjadi masalah bagi para pemuda kita. Namun perkembangan itu sendiri dijadikan sebuah spirit untuk membuktikan kehebatan sebagai pemuda dengan lebih intens belajar dan memahami ajaran agama. Jangan dijadikan alasan bahwa taat agama adalah orang yang ketinggalan zaman, tapi dengan taat itulah kita buktikan relevansi dan eksistensi agama itu sendiri. Dengan gaya tetap kekinian tapi tidak menyimpang ajaran agama, sosial dan etika. Maka kata Muhammad al-Fatih ${ }^{20}$ kehidupan ummat muslim dalam berbangsa dan berbudaya juga dapat dimanifestasikan dengan baik melalui pesan yang dibawa Rasulullah saw dan tuntunan yang dibangun selama beliau menjadi ut usan Allah swt. ${ }^{21}$

Keberadaan pemuda di Indonesia sesungguhnya dapat menjadi aset yang berharga bagi masa depan bangsa ini ke arah yang lebih baik dan mampu berdiri sejajar dengan bangsa lain dalam segala bidang. ${ }^{22}$ Dengan tetap mempertahankan keislaman dan keindonesiaanya tanpa terpengaruh dengan ajaran-ajaran yang bersifat anarkis, lebih-lebih menentang ideologi Pancasila. Karena memperthankan identitas itu sangat mahal dan sangat berharga, dari sana lah bangsa akan punya nilai. Berawal dari pemuda yang cerdas dan selalu melakukan aksi perubahan yang lebih baik dengan berpedoman pada al-Qur'an dan sunnah Nabi Muhammad saw.

Dalam bukunya yang berjudul Al-Jailu Nasrul Mansyuud Yusuf Qardhawi mengatakan: "siapa saja menelaah as-Sunnah dan membaca al-Hadis, niscaya mengetahui jelas generasi idaman ini dengan matahatinya dan mengenalinya secara rinci. Tentu berbicara tentang generasi yang dimaksud disana adalah para pemuda. Nabi saw. Melihat generasi semacam ini adalah generasi yang selamat di anatara tujuh puluh tiga golongan yang binasa. Generasi semacam ini adalah generasi yang tidak mengikuti hawa nafsunya seperti anjing yang setia terhadap majikannya. Mereka

${ }^{20}$ Salah satu Dosen dan Guru Besar UIN Sunan Kalijaga Yogyakarta dalam bidang Ilmu Tafsir dan Hadis

21 Muhammad al-Fatih Suryadilaga, "Kontekstualisasi Hadis dalam Kehidupan Berbangsa dan Berbudaya" dalam journal KALAM, Volume 11, Nomor 1, Juni 2017, hlm. 216

${ }^{22}$ Wahyu Ishardino Satries, "PERAN SERTA PEMUDA DALAM PEMBANGUNAN MASYARAKAT” Jurnal Madani Edisi I/Mei 2009, hlm. 90 
tidak akan keluar dari agama seperti anak panah keluar dari busurnya, bahkan mereka selalu komitmen kepada ajaran Rasulullah saw. dan para sahabatnya". ${ }^{23}$

\section{G. Perhatian Dunia Kepada Kaum Muda}

John Kennedey, seorang negarawan dari Amerika berkomentar tentang krisis sikap para remajanya. Ia mengatakan, "Andai mereka disuruh berperang, hanya satu dari tujuh pemuda yang berani menghadapi musuh". ${ }^{24}$ Bisa kita melihat, bahwa pemuda yang di gambarkan oleh John Kennedey sudah kehilangan jati diri sebagai orang pemuda yang memiliki tanggung jawab. Lebih-lebih mereka sudah kehilangan keberanian dalam memperjuangkan hak. Dalam kasus ciri-ciri pemuda yang seperti itu, Nabi pernah menyingungnya bahwa "suatu saat umatnya akan cinta terhadap dunia dan takut terhadap mati". Arti kata mati sebenarnya bukan kehilangan nyawa saja, tetapi yang dimaksud dengan mati disana juga bisa bermakna kehilangan rasa tanggung jawab dan konsekuensinya atas apa yang semestinya menjadi kewajiban.

Islam sangat memperhatikan persoalan kepemudaan, hal ini dapat dilihat dalam setiap pertemuan para cendikiawan muslim, permasalahan pemuda senantiasa dibahas, misalnya dalam muktamar yang diselenggarakan oleh Rabitatul Alam Islami di Kairo. Juga dalam pertmeuan yang diadakan di Makkah pada pertengahan bulan. Sebelum itu yakni pada pertemuan yang diselenggarakan di Beirut, permasalahan pemuda tidak luput dari pembahasan. Meskipun sebenarnya pertemuan itu sendiri terfokus pada permasalahan-permasalahan mendasar kaum muslimin di dunia. Namun karena pentingnya masalah kepemudaan, pembahasan mengenai hal itu tidak pernah terlewatkan. Selain membahas tentang krisis moral kaum muda, pertemuanpertemuan itu juga menganggap perlu untuk menggalakkan pendidikan mereka kearah depan yang lebih baik. 1990), hlm. 36

${ }^{23}$ Dr. Yusuf Qardhawi, “Generasi Idaman”, (Jakarta: Media Da’wah,

${ }^{24}$ Hasan Al Banna dkk, Pemuda Militan, (Solo:CV. Pustaka Mantiq, 1992), hlm. 41 
Kesimpulan mengenai pentingnya memberantas krisis moral pemuda dengan pendidikan akhlak yang baik dihasilkan dalam muktamar tahunan yang diselenggarakan di Kuwait tahun 1970. Muktamar tersebut mendahului pertemuan Tokyo di Jepang yang membahas topik yang sama pada tahun itu juga. ${ }^{25}$

\section{H. Pemuda Dalam as-Sunnah.}

Teringat cerita seorang pemuda yang ingin mendaftarkan dirinya sebagai prajurit dalam sebuah peperangan yang dipimpin Rasulullah saw. Ia datang membawa pedang yang panjang pedangnya itu melebihi tinggi badannya. lalu dengan tegas Rasulullah saw. menolak niatannya karena ia belum memiliki seni berperang. Lalu pemuda itu pulang dan berdiskusi dengan ibunya, lalu ia terus belajar dan mencari kelebihan yang ia miliki sehingga ia pun menemukan bahwa ia pandai menulis dan berbahasa. Dikemudian hari Rasulullah saw. mengangkat beliau sebagai sekretaris pribadi. Dan pemuda itu adalah Zaid bin Tsabit. ${ }^{26}$

Melihat kisah diatas ada dua poin yang perlu dicermati, yaitu semangat perjuangan (struggle) dan selalu berupaya menggali potensi diri. Keberanian Zaid bin Tsabit bisa dijadikan kiblat untuk selalu mengobarkan api perjuangan menjaga agama dan bangsa. Segala hal ia coba baik berperang namun ditolak karena faktor usia. Tapi kesempatan bukan berarti musnah demi perjuangan menjaga agama dan bangsa, tapi dia mencoba menggali potensinya sebagai jurnalis sehingga diangkat menjadi sekretaris pribadi Nabi yang namanya harum sampai saat ini bahwa ia adalah orang yang berperan besar dalam pengkodifikasian al-Qur'an.

Ada sebuah hadis:

${ }^{25}$ Hasan Al Banna dkk, Pemuda Militan, (Solo:CV. Pustaka Mantiq, 1992), hlm. 50

${ }^{26}$ https://www.facebook.com PERAN SERTA PEMUDA DALAM

/Berbagi.Kisah.Inspirasi.Islam/posts/344920978957994, dikutip tanggal 2 November 2017. 


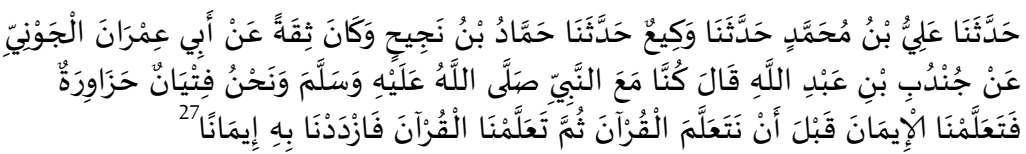

"Telah menceritakan kepada kami Ali bin Muhammad berkata, telah menceritakan kepada kami Waki' berkata, telah menceritakan kepada kami Hammad bin Najih -ia tsiqah (terpercaya) - dari Abu Imran Al Jauni dari Jundub bin Abdullah ia berkata; "Ketika kami bersama Nabi shallallahu 'alaihi wasallam, pada saat itu kami merupakan sosok pemuda-pemuda yang kuat. Kami belajar iman sebelum mempelajari al-Qur'an, kemudian kami mempelajari al-Qur'an, maka dengan begitu bertambahlah keimanan kami."

Dalam hadis ini dijelaskan peran seorang pemuda yang memiliki ketangguhan dan semangat yang tinggi dalam belajar. Bisa kita tinjau untuk menjadi pemuda Islam yang baik tidak cukup hanya belajar saja atau kecerdasan Inteleketual saja, namun juga tak kalah pentingnya adalah kecerdesan spiritual dan emosional sebagai penyeimbang jiwa dan raga agar tercipta pemuda yang cerdas dan taat dan berdampak membawa agama dan bangsa bermartabat. ${ }^{28}$

Dari kutipan hadis diatas bisa diambil pelajara bagaimana pemuda Islam Indonesia semesstinya. Sehingga mereka benarbenar menjadi generasi harapan untuk waktu yang terus berlanjut. Tiada lain yaitu harus menguasai ilmu pengetahuan, menghormati akal, percaya pada bukti, menolak cerita bohong, tidak mengikuti prasangka dan keinginan hawa nafsu. Suatu generasi yang mempelajari al-Qur'an, berpikir itu wajib, merenung adalah ibadah, mencari ilmu adalah jihad, dan bersikap statis atas tradisi kuno karena sekedar kekunoannya adalah suatu kebodohan dan kesesatan. Dan sesungguhnya taklid buta kepada nenek moyang dan kepada para pembesar adalah suatu kerusakan dan kehancuran. Itulah sebabnya generasi idaman ini senantiasa berpikir sebelum menetapkan sesuatu, belajar sebelum beramal, meneliti adil sebelum mempercayai, berencana sebelum melaksanakan sesuatu. Dan tidak hendak menerima ketetapan

${ }^{27}$ Sunan Ibnu Majah 60, juz:1, hlm. 23

28 Asef Umar Fakhruddin, "Peran Generasi Muda dalam Keberlangsungan Pendidikan Islam”, Dalam Journal INSANIA|Vol. 11|No. 2|Jan-Apr 2006, hlm. 2 
tanpa ada bukti dan tidak menerima pengakuan sebelum ada data. ${ }^{29}$ Karena tidak jarang pemuda Islam Indonesia terkecoh dan tertipu baik dari segi keilmuan maupun social. Semua itu terjadi karena antusias mencari pengetahuan, mengantisipasi kesalahan, kekeliruan bahkan manipulasi sangat minim. Akan tetapi jika kita giat dan kiat menepis semua itu, pemuda Islam akan tangguh seperti yang tergambar dalam hadis tersebut dengan gemar mempelajari al-Qur' an beserta isinya pada Nabi Muhammad saw.

\section{Penutup}

Setidaknya kesadaran memang akan terus relevan diaktualisasikan. Karena menurut KH. Sinwani Adra'I, BA beliau mengungkapkan: "kebenaran akan selalu tetap diminati oleh setiap insan". Karena tidak ada kebaikan yang sia-sia. Pemuda adalah titipan Tuhan kepada suatu bangsa dan agama. Karena pemuda yang akan melanjutkan segala tanggung jawab selanjutnya dimuka bumi terutama bumi Indonesia saat ini. Oleh sebab itu, orang tua harus benar-bemr mengarahkan pada anakanaknya sebagai genersi selanjutnya ke jalan yang baik.Seperti yang telah di lakukan oleh Luqman yang memberikan arahan secara intelektual dan emosional pada anaknya agar teguh dan patuh serta tidak menyekutukan Allah swt.

Jika syeikh al-Maraghi mengatakan "Islam sekarang berada diantara kebodohan putra dan putrinya" ungkapan itu jangan kita jadikan justifikasi yang nyata, akan tetapi kita jadikan sebuah cambuk kepada para pemuda dan pemudi Islam saat ini yang mulai tidak peduli dengan dunia keilmuan namun cenderung dengan kelakuan dan pergaulan yang kurang mengunt ungkan bagi Agama, Bangsa dan Negara, lebi-lebih pada diri sendiri namun dampaknya sangat besar bagi kehidupan bersama. Yaitu akan

\footnotetext{
${ }^{29}$ Dr. Yusuf Qardhawi, “Generasi Idaman”, (Jakarta: Media Da’wah, 1990), hlm. 41-42

${ }^{30}$ Pengasuh Pondok Pesantren DARUS SALAH AN-NAWAWIYAH Modung, Bangkalan, Madura. Beliau merupakan ulama karismatik di daerahnya yang memiliki banyak jamaah karena dinilai ajarannya selalu melakukan relevansi atau kontekstualisasi ajaran Islam pada daerahnya, terutama pada para santri-santrinya.
} 
terjerumus dalam kehancuran apabila kemunkaran terus dibiarkan dan dilakukan para pemuda.

Seruan Nabi perlu dijadikan sebagai momentum yang urgens bagi kehidupan para pemuda saat ini dan seterusnya. Selain merupakan sebuah kewajiban mengikuti tuntunan Nabi Muhammad saw, disisi lain akan menjadi sebuah keistimewaan tersendiri yang akan berdampak menjadi manusia yang selamat dunia dan akhirat. Selamat dunia kita harus peka sosial, menekuni segala bidang keilmuan, sosial, ekonomi, politik dan sebagainya agar menjadi pemuda yang tanguh. Namun tetap dalam satu koridor mengikuti ajaran Nabi Muhammad saw sebagai manusia terbaik yang diutus Allah untuk menyebarkan Islam yang memberi rahmat bagi seluruh alam.

\section{DAFTAR PUSTAKA}

Al Banna, Hasan dkk, Pemuda Militan, Solo: CV. Pustaka Mantiq, 1992

Fakhruddin, Asef Umar "Peran Generasi Muda dalam Keberlangsungan Pendidikan Islam”, Dalam Journal INSANIA Vol. 11. No. 2 Jan-Apr 2006

Muthahhari, Murtadha, Menjangkau Masa Depan, Bandung: Mizan, 1996

Moekti, Hari, Generasi Pemuda Islam, Bandung: Remaja Rosdakarya, 1998

Qardhawi, Yusuf, “Generasi Idaman”, Jakarta: Media Da'wah, 1990

Rahmah, Itsna Fitria "Etika Pergaulan Remaja Muslim yang Ramah Ditinjau dari Konsep Peace Education; Studi di SMA Islam Al Azhar 14 Semarang", Jurnal Pendidikan Madrasah, Volume 1, Nomor 2, November 2016 
Satries, Wahyu Ishardino "PERAN SERTA PEMUDA DALAM PEMBANGUNAN MASYARAKAT", Jurnal Madani Edisi I/Mei 2009

Suryadilaga, Muhammad al-Fatih "Kontekstualisasi Hadis dalam Kehidupan Berbangsa dan Berbudaya" dalam journal KALAM, Volume 11, Nomor 1, Juni 2017 